\title{
Demystifying Qatar's Pro-Revolution Monarchy: Old Rivalries, New Geopolitical Motives
}

\author{
ALI ABO REZEG \\ Social Sciences University of Ankara \\ ORCID No: 0000-0002-2226-9970
}

ABSTRACT Unlike other Arab monarchies, Qatar has embraced a supportive position toward the Arab revolutions since the moment they broke out in late 2010. In fact, Qatar's Al Jazeera network was an essential media mobilizer for the Arab masses and a major promoter of the revolutionary change process in the region, hosting pro-revolution Arab intellectuals, and broadcasting pro-reform messages. Qatar welcomed the Tunisian Revolution, financially backed the country in its transitional stage, and behaved the same with the subsequent Egyptian and Yemeni cases. What's more, Qatar made efforts to encourage both Arab and international support for humanitarian interventions in Libya and Syria, and generously backed the revolutionary forces there both financially and militarily. Given the fact that Qatar's political system is of the conservative-monarchic type, this paper aims to review the dynamics and geopolitical interests that drove Doha to embrace a pro-change policy in the region during the Arab Spring, with a view to better understanding what has become known as the 'Qatari Oxymoron' or 'Qatari Exceptionalism,' and the ensuing $d y$ namics that led to the Gulf crisis of 2017 -the most difficult crisis among the GCC states since the organization's establishment in 1981.

Keywords: Qatar, Arab Spring, Revolutions, Motives, Geopolitical Reach

Insight Turkey 2021

Vol. 23 / No. 3 / pp. 181-207 


\section{Introduction}

hroughout history, monarchies have been largely skeptical of revolutionary change taking place within their geopolitical reach, with the majority positioning themselves in opposition to the revolutionary movements promoting such change. Since the French Revolution (1789), the Bolshevik Revolution (1917), and the Iranian Revolution (1979), international factors have played a crucial role in the success or failure of various revolutions. Exporting revolutionary ideas and principles abroad has been the most critical issue of concern to the neighbors of revolutionary countries, especially monarchies, prompting them in some cases to establish counter-revolutionary coalitions with a view to foiling these movements, or at least containing them.

In the case of the Arab Spring revolutions that erupted in Tunisia in late 2010 and in Egypt, Libya, Yemen, Syria, and Bahrain in early 2011, Saudi Arabia and other Arab monarchies, especially the United Arab Emirates (UAE), played crucial roles in thwarting these revolutions and the nascent democratic process they promoted. Saudi Arabia even provided a safe haven for Tunisia's fugitive President, Zine el-Abidine Ben Ali, and former Yemeni President Ali Abdullah Saleh. What's more, Riyadh, along with other Gulf monarchies, sent 'Peninsula Shield' forces to help quell the protests that erupted in Bahrain. With the exception of Qatar, the Gulf monarchies welcomed and financially supported Egypt's military coup against Mohammed Morsi, the country's firstever democratically elected leader. Following the coup in Egypt, Riyadh, and Abu Dhabi also extended assistance to Libyan General Khalifah Haftar, who continues to lead counter-revolutionary forces in the North African country.

Unlike the other Arab monarchies, Qatar adopted a supportive position vis-àvis the Arab Spring uprisings. Indeed, Qatar's Al Jazeera media network played a major role in mobilizing the Arab masses that took to the streets to demand change, and in promoting the revolutionary process. Qatar welcomed the Tunisian Revolution, generously supported the country during its transitional stage, and behaved the same in the Egyptian and Yemeni cases. Qatar also exerted efforts to drum up Arab and international support for humanitarian intervention in post-revolution Libya and Syria and is known to have sent military and financial support to Syrian revolutionary forces. Al-Thani's emirate was even accused by its monarchial neighbors of covertly assisting the peaceful protests that erupted in Bahrain.

Qatar's pro-Arab Spring policies led to an unprecedented tension between it and its royal neighbors; before bilateral ties were indefinitely suspended when Saudi Arabia, the UAE, and Bahrain withdrew their ambassadors from Doha in 2014. The three countries, plus Egypt, imposed a comprehensive boycott and embargo on Qatar in the summer of 2017. 
Given that Qatar's political system is a conservative monarchy, this study aims to review the dynamics and geopolitical interests that drove Doha to embrace a pro-change policy in the region. Throughout history, conservative monarchies have been extremely wary about revolutionary changes taking place within their geopolitical reach, and have spared no effort to undermine radical change by forming counter-revolution alliances, waging wars against the revolutionary state, and in some cases addressing the needs of dissatisfied domestic groups. ${ }^{1}$ The importance of the current study derives from its assessment of the correlation between regime type and states' reactions to nearby revolutionary upheavals. Looking at the exceptional case of Qatar, this study challenges current theories explaining the role of conservative monarchic regimes in countering revolutions in neighboring states. The existing theories interpret the Arab monarchies' reactions to the Arab revolutions as little more than attempts to preserve the status quo.

This paper discusses the dynamics behind the exceptionalism in Qatari policies and identifies thirst for power as the main motive that drove Doha to embrace these policies; this is evident in Qatar's ambitious political elite, its challenging of Saudi hegemony over the Gulf, and its competition with the UAE in terms of regional interests. A cultural aspect is also explored, as evidenced in the ruling family's references to Qatar's culture to justify and explain their policies. The domestic dynamics of Qatar's tribal community are also noted, as this factor helps further elucidate why Qatar was eager to adopt an independent foreign policy toward the Arab revolutions.

\section{Main Driving Factors}

\section{A Strive for Power}

A strive for more power and influence in the Middle East was the main driving factor that prompted the monarchic state of Qatar to adopt exceptional policies during the Arab revolutions. An eagerness for more political clout was an inevitable outcome of the rise of Qatar's ambitious political elite since the mid1990s. This was clear in the policies engineered by the elite, which governed the monarchy in the period from 1995 to 2013, which came to be known as the time of the 'Two Hamads' (Emir Hamad bin Khalifa al-Thani and his Prime Minister and Foreign Minister, Hamad bin Jassim).

Resisting Saudi hegemony over the Gulf was another way for Qatar to assume regional power, most importantly by taking advantage of the political vacuum 
Al Jazeera was emboldened to broadcast programs that would have been considered taboo in the past, providing, for example, details of the 1996 Saudi/UAE-backed coup attempt against Qatar and government corruption in the UAE

left by the fall of Egypt's Mubarak regime, Saudi Arabia's chief regional ally. Doha also competed with the UAE for influence in the Middle East, with al-Thani standing against al-Nahyan's bid to counter the Arab revolutions, especially those in Egypt, Tunisia, and Libya. The U.S. support and protection also proved to be a critical manifestation of Qatar's keenness to accumulate power. Doha spared no effort to convince the U.S. that it was the best Middle Eastern state to forge and leverage useful ties with Islamist groups in the region, especially the Muslim Brotherhood, which attained power in different parts of the Arab world following the political earthquake of 2011.

\section{An Ambitious Political Elite}

Personal traits are significant when analyzing the uptick of Qatari regional influence since it coincides with Emir Hamad bin Khalifa's rise to power. Although Hamad's rule began in 1995, his true rise began with the discovery of massive gas reserves in Qatar in 1997 (around 5.6 percent of global reserves), which allowed him to adopt a proactive foreign policy over the last two decades. ${ }^{2}$ Emir Hamad was accompanied by an ambitious political elite, particularly his Prime Minister, Hamad bin Jassim. Both men had a strategic vision for assuming influence in the region, not only for purposes of survival but also for achieving leverage. ${ }^{3}$ This could either be accomplished by bandwagoning off Saudi Arabia, as other Gulf states do or by having an independent foreign policy -the latter route would allow the small state of Qatar to achieve relevance on the regional and international levels. ${ }^{4}$

The two Hamads ${ }^{5}$ saw that Qatari state-building was inextricably linked to the emergence of a robust and autonomous foreign policy. ${ }^{6}$ Following his seizure of power from his father in a bloodless coup, Emir Hamad bin Khalifa was anxious to take an independent path and uncouple his country's foreign policy from that of Saudi Arabia. Like the other Gulf States, Qatar's foreign policy to a great extent mirrored that of Saudi Arabia until the mid-1990s, when the Gulf monarchy, under the leadership of Emir Hamad bin Khalifa al-Thani, carved out its own independent path. ${ }^{7}$ This was soon reflected by his establishment of the Al Jazeera news network in 1996, with dozens of Arab journalists -many of whom held anti-Riyadh views- joining the news platform. ${ }^{8}$ It was also seen in his rush to normalize ties with Iran, with which Qatar shares enormous offshore gas fields, and Israel, after the latter took part in the 1997 Doha Conference. ${ }^{9}$ The emir's particular personality, reflected in the way he was running 
the state, made his foreign policy unpredictable, idiosyncratic, and successful. This could be seen in his effective mediation efforts, resulting in close ties with Iran and Hamas, a positive relationship with the U.S., and, perhaps most importantly, his pro-Arab Spring policies. ${ }^{10}$ The emir, in his speeches at UN General Assembly meetings, clearly voiced his country's policy of backing anti-corruption and anti-authoritarian revolutionary change in the region with a view to achieving what he termed "reconciliation between the [Arab] people and their states."11

Meanwhile, his ambitious premier and Foreign Minister, bin Jassim (19952013), was becoming known as the engineer of Qatar's increasingly proactive foreign policy in the region. ${ }^{12}$ Emir Hamad bin Khalifa trusted him and gave him the powers he needed to manage the country's affairs on the internal and external levels. Bin Jassim also acted on the regional and international levels by managing the country's investments through the massive Qatar Sovereign Fund. ${ }^{13}$ He was a co-founder of Al Jazeera, which became bin Khalifa's trump card in his efforts to offset Saudi hegemony and oppose the blockade imposed on Qatar in 2017. ${ }^{14}$ Al Jazeera was emboldened to broadcast programs that would have been considered taboo in the past, providing, for example, details of the 1996 Saudi/UAE-backed coup attempt against Qatar and government corruption in the UAE. ${ }^{15}$

Hamad bin Jassim also pursued Qatari mediation in the Middle East and Africa, which has been the main dynamic behind the country's reflective foreign policy over the last two decades. ${ }^{16} \mathrm{He}$ convinced Hamas to come to Doha in 2012 and take up a temporary residence there, making the Gulf monarchy a political incubator for the Palestinian resistance group. Qatar also provided generous financial support to both the Fatah-led Palestinian authority and Hamas. This support, along with the hosting of reconciliation meetings between the two rivals, allowed Qatar to play a crucial role in efforts to resolve the Palestine issue and attract western powers that sought to engage with Hamas. ${ }^{17}$ Due to his county's soft diplomacy and successful mediation efforts in both Africa and the Arab world, bin Jassim was dubbed the 'Gulf Fox.' He presided over a diplomatic breakthrough between Sudan and Chad in 2009, a historic peace deal in Darfur in 2011, and an agreement to end the longstanding rift between Eritrea and Djibouti in 2011. ${ }^{18}$

Bin Jassim also played a pivotal role in drumming up regional and international support for revolutionary forces in Libya in April 2011, Yemen in May 2011, and Syria in January 2012. ${ }^{19}$ He led his country's delegation at meetings aimed at ending the dispute between Doha and Riyadh over the territory of al-Udeid, where he later convinced the U.S. to establish an enormous military base in 1996. The al-Udeid airbase is now considered the largest military base that includes U.S. forces in the region; it played a role in the failure 


\section{Qatar's soft power was manifested mainly through tourism conferences, think tanks, and research centers, the Qatar Foundation for Education, and the Qatar Charity}

of a Saudi-led bloc of nations to launch a military offensive against Qatar in $2017 .{ }^{20}$ Qatar wanted to see bin Jassem assume the world's top diplomatic post, thus, his eyes were on the UN Secretary-Generalship after Ban Ki-moon's term ended in 2016. A report in the Telegraph indicated that Qatar's former Prime Minister was being considered as a possible candidate to replace Ban after the emir offered to back him for the prestigious position. ${ }^{21}$ These aspirations were fostered through a distinguished advisory body. Although Qatar is a tiny state with a very limited population, it has managed to forge its own cultural, economic, media, and sports status in the region by following what we can term a 'status-making' policy. ${ }^{22}$

Qatar saw that enjoying status in the region was key to protecting its existence. To achieve and maintain this status, Doha spared no effort in projecting soft power. According to both history and geopolitical theories, it is difficult for small states to achieve such an oversized status within their geopolitical surroundings, and this also applies to small Gulf monarchies. Qatar's soft power was manifested mainly through tourism conferences, think tanks, and research centers, the Qatar Foundation for Education, and the Qatar Charity. ${ }^{23}$ Thus, Qatar was exceptional in this regard given the presence of its ambitious ruling elite. Its ambitious leaders attracted hundreds of advisors from throughout the Arab world, especially from Egypt, Palestine, Sudan, Syria, and Yemen. These experts and advisors played a critical role in the success of the mediation efforts in which Doha has engaged over the past two decades. Qatar's rise has been accompanied by its tremendous oil wealth, which allows the country's leadership to translate its regional ambitions into reality. Kuwait, Bahrain, and Oman are also wealthy countries, but they all lack the will and ambition for regional status. ${ }^{24}$

It has been asked whether the ascendancy of Emir Tamim in 2013 will affect the ambitious foreign policy that the 'Two Hamads' pursued for almost 18 years. While Majed al-Ansari argues that Qatari foreign policy has adopted a 'withdrawal approach' since 2014, ${ }^{25}$ David Roberts says Qatari foreign policy is unlikely to change under Emir Tamim, who came to power after his father's abdication, ${ }^{26}$ for four reasons. First, it is not easy to change a decades-long policy via a decree, as the communications and good ties Emir Hamad forged with certain groups (the MB, Azmi Bishara's team, Hamas, etc.) remain unchanged. Second, it will be difficult for Tamim to behave in a way that contra- 


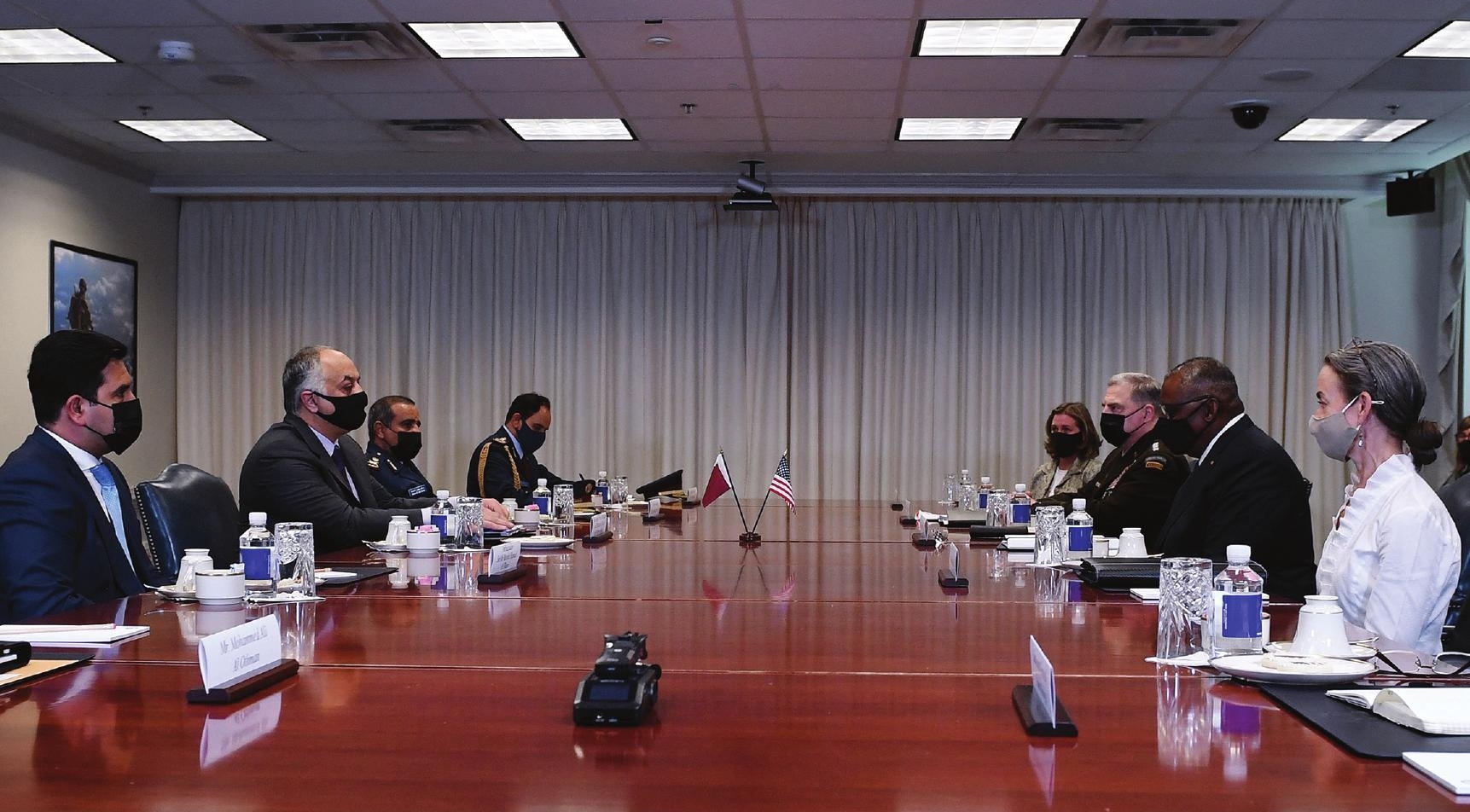

dicts the life's work of his father. The latter was an iconic leader who continues to cast a long shadow over the entire Arab world, not to mention the fact that Tamim's mother, Moza bint Nasser, still plays a key role in Qatari politics. Third, Tamim's first months in office indicate that his priority is the foreign economy, not foreign policy. Fourth, Emir Tamim came to power amid traumatic regional shocks, including the 2013 Egypt coup and the 2014 Gulf crisis, prompting him to focus more on domestic fiscal affairs. ${ }^{27}$

\section{Challenging Saudi Regional Hegemony}

The emergence of the first Qatari-Saudi rift dates back to the 1960s, when the two countries differed over border demarcations, despite the fact that a demarcation agreement was signed in 1965. Saudi Arabia ceded parts of the Buraimi Oasis to the UAE in return for the latter's cession of the coastal strip known as 'al-Udid.'28 With this move, a common border no longer existed between the UAE and Qatar, leading to complaints by the latter that the step had turned it into a Saudi enclave, forcing Qataris to go through Saudi Arabia in order to reach the UAE. ${ }^{29}$ This way, Riyadh sought to tighten its grip on its Qatari neighbor, as it had with Bahrain. Because geographical control leads inevitably to political hegemony, Saudi Arabia opposed the construction of a sea bridge between the UAE and Qatar in 2005. ${ }^{30}$

In 1992, armed clashes erupted on the Saudi-Qatari border after Saudi forces allegedly attacked a Qatari border post, leaving two Qataris and a Saudi officer dead. Additionally, the Qatari government accused members of the Saudi-backed Bani Murra ${ }^{31}$ tribe of planning the 1996 coup attempt in co-

U.S. Defense

Secretary Lloyd Austin $\left(2^{\text {nd }} R\right)$, with Chairman of the Joint Chiefs of Staff General Mark Milley $\left(3^{\text {rd }} \mathrm{R}\right)$, meets Qatari Defense Minister Khalid Bin Mohammed al-Attiyah ( $2^{\text {nd }} \mathrm{L}$ ) at the Pentagon in Washington, D.C., on August 19, 2021.

OLIVIER DOULIERY / AFP via Getty Images 
Saudi Arabia, throughout the $20^{\text {th }}$ century, acted as the Gulf's 'big sister,' with its kings expecting its Gulf neighbors to adopt foreign policies in line with its interests operation with ousted Emir Khalifa bin Hamad al-Thani. In 2000, Saudi Crown Prince Abdullah bin Abdul Aziz boycotted an Organization of Islamic Cooperation (OIC) summit held in Doha to protest what he described as "the presence of an office for the Israeli trade representative in Qatar." ${ }^{32}$ In 2002, Saudi Arabia recalled its ambassador to Qatar after a Saudi dissident appeared on Al Jazeera and criticized the Saudi royal family. ${ }^{33}$ In the same year, another coup was attempted against Emir Hamad, which Doha accused Saudi Arabia of orchestrating. ${ }^{34}$ The surprise participation of former Iranian President Mahmoud Ahmadinejad at a Gulf Cooperation Council (GCC) summit in Doha also impacted Saudi-Qatari relations, with Saudi daily al-Sharq al-Awsat quoting senior Gulf officials as saying that they had not been informed of Ahmadinejad's presence in advance, going on to describe his participation as 'disgusting,' reflecting Saudi anger over Qatar's 'unilateral' move. ${ }^{35}$

Qatari-Saudi relations worsened further after Qatar's support for the 2011 revolutions that took place in Tunisia, Egypt, Libya, Yemen, and Syria. Saudi Arabia views extraordinary changes affecting any Arab regime, whether through revolution or displacement, in a negative light, believing that any abrupt change (revolution, rebellion, or uprising) constitutes fitna (sedition), and has ruinous effects ${ }^{36}$ that could put its century-old absolute monarchy in danger. ${ }^{37}$ For this reason, Saudi Arabia believed that the spark of revolution, which was first ignited in Tunisia, should have been snuffed out immediately and its advocates swiftly suppressed..$^{38}$

It is worth mentioning that the Arab Spring came at a time of regional polarization that amounted to a kind of 'cold war' between Iran and Saudi Arabia. ${ }^{39}$ The outbreak of protests in five Arab countries served to amplify Saudi anxieties, while Qatar viewed it as an opportunity to reverse Saudi hegemony and project its own power on a regional scale. Conflicting Saudi and Qatari views toward the Arab Spring not only revealed the rivalry between them, but confirmed the fact that, since the early years of the 1900s, and since the British withdrawal from the Gulf, Riyadh had striven to subordinate its neighboring monarchies and treat them as dependent entities that should unquestioningly follow its foreign policy. ${ }^{40}$

Saudi Arabia, throughout the $20^{\text {th }}$ century, acted as the Gulf's 'big sister, ${ }^{311}$ with its kings expecting its Gulf neighbors to adopt foreign policies in line with its interests. It wanted these states under its heel on the economic, social, and religious levels. ${ }^{42}$ The Bahraini case is a clear example of Saudi expectations 
vis-à-vis neighboring monarchies since Bahrain has faithfully replicated Saudi policies, including Manama's position on the 2017 Gulf crisis. ${ }^{43}$ This was also the case with Qatar -before Khalifa bin Hamad came to power in $1995 .{ }^{44}$ Qatar's refusal to play a subordinate role to Saudi Arabia has been a feature of Doha's policymaking since 1995. Since then, Qatar has adopted an independent foreign policy that has put Doha's interests first and those of the rest of the Gulf second. ${ }^{45}$ A look at some of the Saudi conditions ${ }^{46}$ for ending the blockade imposed on Qatar may make this more understandable. ${ }^{47}$

Independent foreign policymaking was seen as 'evidence of mistrust' by the monarchies neighboring Qatar, as it 'flouts traditions of tribal consensus.' This perspective has been expressed by many writers and commentators close to the Saudi/UAE bloc. Editor-in-chief of the UAE's al-Ittihad newspaper, Mohammed al-Hammadi, said that Saudi Arabia had been outraged by Qatar's independent foreign-policy trajectory, asserting that Doha's behavior "not only challenges Gulf interests but flouts traditions of tribal consensus." ${ }^{48}$ His remarks shed light on the dynamics that led to Saudi anger over Qatar's $A l$ Jazeera channel, which routinely criticizes the Gulf royal families. "The one thing foremost in our Bedouin culture is trust. Today, the UAE, the Saudis, and Bahrain don't trust the Qatari regime." ${ }^{49}$ This shows how difficult it is for any Gulf monarchy to adopt a regional vision that diverges from Riyadh's.

Relations with Egypt were a critical indicator of Qatari endeavors to offset Saudi hegemony. Mubarak's regime had forged 'distinguished' ties with the Saudi authorities, as the latter invested $\$ 7$ billion in Cairo, not to mention the fact that there were 'distinguished personal ties' between Mubarak's family and the Saudi royals. ${ }^{50}$ The enormous Saudi influence on Egypt, on the economic level, in particular, constituted a stumbling block for Qatari intervention in the country. ${ }^{51}$ Defying Saudi influence in Egypt can be seen as one of Doha's driving policies in terms of its decision to back the revolution in Egypt, ${ }^{52}$ and came parallel with the Qatari strategy of countering Saudi hegemony in the Gulf. ${ }^{53}$ Following the Arab Spring, the Gulf monarchies' reactions varied from a 'wait-and-see' policy to explicitly countering pro-change movements in the Arab world. Regarding Egypt, Qatar was the only Gulf monarchy that reacted positively to the revolution, which gave Doha a foothold in a strategically vital country that had been the exclusive jurisdiction of Saudi Arabia during Mubarak's era. ${ }^{54}$

It is also worth mentioning the role Qatar played (directly and indirectly) in breaking a taboo imposed on the Arab monarchic regimes since their establishment. ${ }^{55}$ The radical change that hit the regional system built a half-century earlier, and the rise of the monarchic Gulf states encouraged these states to defend the international system that recognized the legitimacy of monarchic regimes. ${ }^{56}$ However, the international system, which is composed of democratic 
republics and constitutional monarchies, has been validated in different parts of the world, except for the Gulf. The Arab Spring constituted a real danger for these monarchies, mainly Saudi Arabia, which viewed the Qatari royal family's support for the Arab Spring with a great deal of suspicion. Saudi Arabia saw this support as part of efforts to erode the legitimacy of the Gulf's monarchic regimes, thus posing an existential threat to these monarchies, especially Saudi Arabia and Bahrain, which were hit hard by protests in early $2011 .^{57}$

\section{Competing Emirati Regional Ambitions}

Despite the fact that the period following independence saw normalized ties between the UAE and Qatar, many developments took place on the regional level that turned the two countries into rivals. This can be seen in the failed coup attempt in 1996, Qatar's winning 2010 bid to hold the World Cup in 2022, tribal jealousies, and most recently, the Arab Spring.

On June 27, 1995, Qatari Sheikh Hamad bin Khalifa al-Thani led a bloodless coup against his father, Khalifa bin Hamad, who was on an official visit to Switzerland at the time. The deposed emir refused to recognize the new regime and decided to reside in Europe before moving between the UAE, Saudi Arabia, and Bahrain. ${ }^{58}$ The three countries, mainly the UAE, later orchestrated a coup to depose Emir Hamad and restore his father, Khalifa, to the throne. This was because the new emir was known, since the very beginning, for advocating for a Qatari foreign policy independent of Saudi Arabia. He also wanted to establish good ties with Iran and restore ties with Saddam Hussein's regime in Iraq. ${ }^{59}$ Furthermore, Emir Hamad's removal of his father represented a blow to other Gulf leaders and a threat to their dynastic principles, ${ }^{60}$ prompting them to support a countermove aimed at restoring the deposed father. ${ }^{61}$

Fahd al-Maliki, one of the Qatari military generals involved in the failed coup attempt, revealed that the UAE had played the most pivotal role in staging and backing the attempt against the Qatari Emir:

Sheikh Zayed, then ruler of the UAE, was the main planner for the coup. He was the one who coordinated with Bahrain through his son Mohammad bin Zayed [Abu Dhabi's current crown prince]. He managed to convince Saudi Arabia to support Sheikh Khalifa... I lived through these events and took part in Sheikh Khalifa's attempt, I sat with Mohammad bin Zayed and Sheikh Zayed, and I heard their intentions. ${ }^{62}$

While the UAE said that its intervention, along with that of Saudi Arabia and Bahrain, had come at the request of the deposed Emir Khalifa, ${ }^{63}$ the incident constituted a turning point in ties among the GCC monarchies, specifically in relations between Doha and Abu Dhabi. ${ }^{64}$ The Qatari-Emirati rivalry -and mutual mistrust- mounted in the wake of the failed coup, especially between 
Qatari Emir Hamad on the one hand and UAE Chief of Staff Mohammed bin Zayed, and security head Hazzaa bin Zayed on the other.

The second factor explaining the UAE-Qatar rivalry in the region is the UAE's outrage over a FIFA decision in 2010 to give Qatar the privilege of hosting the 2022 World Cup. The decision not only outraged the UAE but Egypt as well, where the Arab monarchies were competing for influence. The Mubarak family saw Qatar's successful bid as a personal slight since Egypt had failed in its own bid to host the 2010 World Cup. Egypt thus felt outdone by Qatar, which became the first Arab country to win the distinction. ${ }^{65}$ The World Cup issue was one of the main reasons behind the UAE's hostility and frequent attacks on Qatar. ${ }^{66}$ Analyzing UAE positions and UAE officials' remarks in this regard makes it easier to understand Abu Dhabi's policies in the Gulf in general and toward Qatar in particular. ${ }^{67}$ The American news website The Intercept confirmed these claims in a document leaked from Youssef al-Otaiba, the UAE's ambassador to the U.S. The leaked information revealed that Abu Dhabi had been plotting a propaganda campaign against Qatar with a view to foiling its plans to host the 2022 World Cup. The document outlined a strategy to wage a campaign aimed at defaming Qatar in the hopes of convincing FIFA that Doha was incapable of providing the infrastructure needed to host the global event. ${ }^{68}$

Abu Dhabis attempt to defame Qatar and thwart its plans to host the World Cup came as part of its efforts to expand its influence in the region by pulling the rug out from under the feet of all parties concerned, starting with Qatar, the UAE's chief Gulf rival. ${ }^{69}$ It was also in line with the goals of anti-Arab Spring figures in Egypt, who urged FIFA to stop Qatar from hosting the event. A look at reports from several UAE and Egyptian newspapers and websites from this time makes this abundantly clear. ${ }^{70}$

A third factor explaining the Qatari-UAE rivalry goes beyond mere political interests and has to do with the tribal culture of jealousy, mistrust, and competition. This is not something new. The tribes, scattered for millennia throughout Arabia, have always fought one another, and rivalries run deep in the pasts of both families. ${ }^{71}$ The Gulf ruling families were keen to forge close ties with Egypt, given the latter's regional weight. At the time, the UAE's Sheikh Zayed al-Nayhan had good ties with Mubarak, while al-Thani's relations with the Egyptian regime had been cold since the rise of Hamad bin Khalifa in 1996. This contributed to deepening the two families' rivalry for Egypt's affections. It is significant to recall that the only Arab foreign minister to pay an official visit to Mubarak during the 2011 protests was UAE Foreign Minister Abdullah bin 


\section{It is undoubtedly true that Doha has worked over the last two decades with a range of Islamist forces throughout the Middle East and North Africa}

Zayed al Nahyan, who sought to show solidarity with the embattled Egyptian president. ${ }^{72} \mathrm{Al}$ Nahyan's visit came at a time when Al Jazeera was airing 24hour anti-Mubarak coverage and calling for a change in Egypt. This was to give al-Thani the lion's share of influence in post-Mubarak Egypt, mainly during Morsi's one year in power.

Jocelyn Mitchell, an assistant professor at the Doha campus of Northwestern University, argues: “There's always been competition and jealousy between the Gulf States..., you've got Qatar becoming the face of the Arab world in many aspects..."73 The rivalry was also linked to the high living standards that Qatari citizens had enjoyed over the last decade compared to their Saudi and Emirati counterparts. Qatari citizens enjoyed the world's highest per capita income $(\$ 147,000)$ in $2011,{ }^{74}$ not to mention the country's advanced educational and health systems, considered superior to those found in other Gulf monarchies. ${ }^{75}$

Fourth, the Qatar-UAE rivalry, in terms of policy drivers, was exacerbated during and after the Arab Spring, with Doha backing pro-change groups in the region, mainly Islamists, and Abu Dhabi fiercely defending the status quo. ${ }^{76}$ While the UAE saw Islamist groups as a strategic threat to the Gulf monarchies, Qatar saw them as highly-organized groups sure to sweep any free election they were allowed to take part in, making cooperation with them the wisest course of action. ${ }^{77}$ The UAE-Qatar rivalry was made clear by the tension that rocked the North African Arab countries, namely, Egypt, Tunisia, and Libya. Following the ousting of Mubarak in Egypt, Qatar actively backed Mohammed Morsi, Egypt's first-ever democratically elected president, and generously supported post-revolution governments while hosting opposition groups actively working for change. ${ }^{78}$

By contrast, Abu Dhabi adopted a hostile attitude toward the newly elected Egyptian president as part of its strategy to thwart pro-change movements in the region, mainly Islamist groups, and counter the revolutions in these countries. Abu Dhabi's hostile policies were also evident in its support for anti-Morsi media outlets, which sought to defame and embarrass Morsi, and funds sent to thug groups set up by its agent, Mohammed Dahlan, to sow chaos in the country. ${ }^{79}$ Morsi, in a televised speech, warned of these groups and their efforts to destabilize the state, and sabotage state facilities. ${ }^{80}$ Abu Dhabi's anti-change policies culminated in its support for the 2013 coup d'etat led by Abdel-Fattah alSisi, which put an end to Egypt's democratic experiment. ${ }^{81}$ In Libya, too, Qatar and the UAE embraced opposing positions regarding the revolution, with Doha supporting revolutionary groups and figures (such as Abdel-Hakim Bilhadje and Ali al-Salabi) in 2011 and 2012, and opposing putschist general Khalifa 


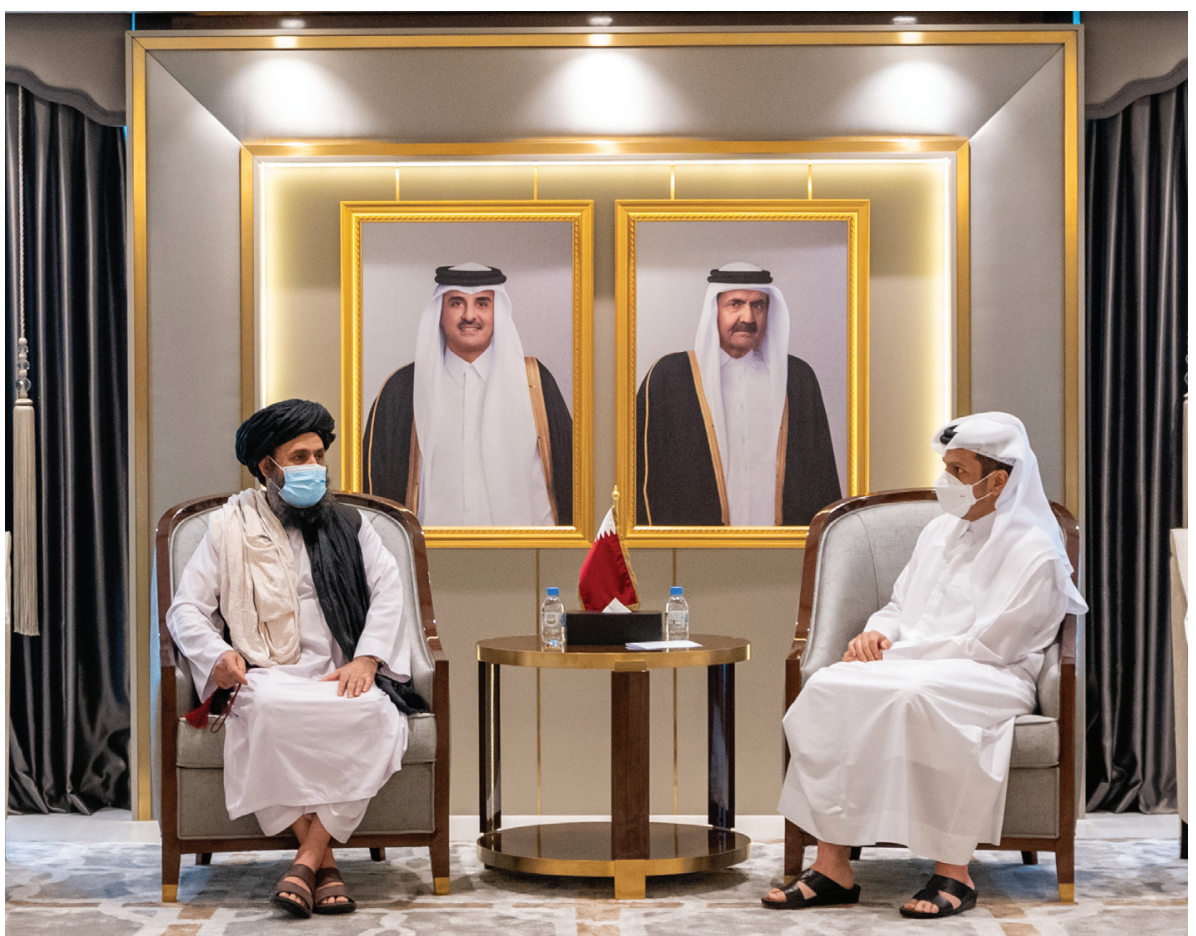

Haftar. Inspired by al-Sisi's coup in Egypt, the UAE generously backed Haftar in his efforts since 2013 to wrest power from Libya's legitimate government. ${ }^{82}$

These points indicate that the UAE-Qatari competition lies at the heart of Qatari endeavors to increase its regional power and influence, with Abu Dhabi striving to prevent Doha's expansion not only due to tribal or personal jealousy among princes but to prevent Qatar from having a foot in the post-revolution countries, especially Egypt.

\section{Ties with the U.S. and Islamist Groups}

Many regional governments, particularly Qatar's Gulf neighbors, ${ }^{83}$ portray Qatar as having an insatiable appetite for backing Islamist groups, including extremist ones, especially since the outbreak of the 2011 revolutions. ${ }^{84}$ It is undoubtedly true that Doha has worked over the last two decades with a range of Islamist forces throughout the Middle East and North Africa (MENA). But there is less basis for the argument that Qatar's rulers -both Hamad and Tamim- are active Islamists, or that their support for Islamist groups in the region is an end unto itself. ${ }^{85}$

Qatar is one of the few Arab countries, if not the only one, to emphasize on different occasions that Islamist groups represent different components of the
Qatari Foreign Minister Sheikh Mohammed Bin Abdulrahman al-Thani (R) meets with Head of the Taliban's Political Bureau in Qatar Mullah Abdul Ghani Baradar (L) in Doha, Qatar on August 17, 2021.

QATARI FOREIGN MINISTRY / AA 
One of Doha's key geopolitical goals was to play on regional contrasts with a view to gaining the trust of conflictual parties, mainly the U.S. and the Islamists
Arab people and should therefore share power within their respective countries via a democratic process. The Qatari leadership is convinced that, since Islamist electoral victories are inevitable, ${ }^{86}$ so too is cooperation with Islamist groups. ${ }^{87}$ The good ties Doha has forged with the U.S. on one hand and with many

Islamist groups on the other is a main dynamic explaining Doha's quest for influence in the region, which culminated in its support for Arab revolutions in Egypt, Tunisia, Syria, and Libya. The Qatari leadership has been keen to gain the trust of conflicting sides (i.e., the U.S. and Islamist groups) with a view to serving as a credible mediator in African and Middle Eastern disputes. ${ }^{88}$ By playing this role, Qatar has become a gateway for Islamist groups seeking to open backchannel talks with the U.S. and has become a trusted ally of Washington, which, for its part, has sought to temper the rise of these groups. $^{89}$

In Egypt, Qatar had a close relationship with the Muslim Brotherhood. In Tunisia, the head of the Islamist Ennahda movement, Rachid Gannouchi, described Qatar as a 'partner' in the revolution, while Islamist groups in Libya voiced similar sentiments. In Syria, Doha worked closely with U.S. intelligence to shape a relationship with the Nusra Front (Jabhat al-Nusra) with the aim of drawing the group away from al-Qaida ${ }^{90}$-a role praised by U.S. policymakers. ${ }^{91}$ Qatar benefited from its relations with the Nusra Front, which it convinced to release hostages and to renounce al-Qaida. ${ }^{92}$

In an interview with $C N N$ in 2014, Emir Tamim discussed the Qatari role in the Arab Spring and Doha's relationship with Islamist movements; his remarks help us understand how Doha took advantage of this role. When asked about his country's controversial support for the Palestinian Islamic group Hamas, he said: "We believe that Hamas is an important component of the Palestinian people. We differ with our friends who classify Hamas as a terrorist group.".93 He noted that the U.S., ten years previously, had asked the Qataris to urge Hamas to take part in Palestinian legislative elections. "The Americans asked us to tell Hamas to engage in the 2006 elections, and Hamas' answer was that we would participate, but do you think that the international community would accept us? My father (Qatari Emir Khalifa bin Hamad) said yes because the Americans told me that." "94 Regarding the evolution of Hamas' political discourse, Emir Tamim added: "I think there is a development in Hamas' political discourse as Hamas has become more realistic these days, Hamas believes in peace and wants peace but the other side (Israel) must believe in peace too and be more realistic." ${ }^{95}$ 
As for Qatar's ties with the Muslim Brotherhood in Egypt, these were also in line with U.S. political orientations in the region. Through these close ties, Doha played a functional role in crystallizing new American trends in the Middle East under the Obama Administration. These trends included the allowance of moderate Islamist groups into the Egyptian government, meaning that the old proscription on Islamists taking part in the political process had been nullified. This new tendency came as a result of the rise of Islamist groups during the Arab Spring in Tunisia, Morocco, Yemen, and Libya, which the U.S. had no choice but to accept as a reality. ${ }^{96}$

One of Doha's key geopolitical goals was to play on regional contrasts with a view to gaining the trust of conflictual parties, ${ }^{97}$ mainly the U.S. and the Islamists. This strategy was adopted in 2001, when many Islamist figures were expelled from Saudi Arabia and other Gulf monarchies following the September 11 attacks. The U.S., however, later sought to establish a dialogue with many of these groups. Coinciding with these developments, Doha hosted a number of regional and international pan-Islamist forums, including the International Union of Muslim Scholars (IUMS), the U.S.-Islamic World Forum, and the alNahda Project for Islamic Youth. ${ }^{98}$

A desire for improved ties with Islamist groups in the Middle East prompted U.S. policymakers to have Doha mediate between them and these groups, especially the Taliban, which has an office in the Qatari capital. ${ }^{99}$ Close Qatar-Taliban ties were the reason why recent U.S.-Taliban talks succeeded in Doha within only two months, while they failed to see any progress in the UAE, despite having gone on for six months. ${ }^{100}$ The UAE ${ }^{101}$ was eager to convince the U.S. that it could replace Qatar in this role by hosting direct and indirect negotiations between the U.S. and the Taliban. ${ }^{102}$ The main reason for the UAE's failure in this regard was the fact that Taliban leaders felt they were being hosted in a 'strange or a hostile environment to Islamists' rather than a sympathetic one. ${ }^{103}$ Therefore, the Taliban was extremely rigid and didn't show any flexibility in negotiations. While in Qatar, by contrast, Taliban leaders felt they were in friendly (or at least neutral) territory where they could 'make concessions and get U.S. concessions in return.' ${ }^{\prime 04}$ Qatar has not only gained regional influence through its role as mediator; it has also been given space by the U.S. in which to maneuver, especially in regard to Al Jazeera. ${ }^{105}$ Al Jazeera was the only Arab media platform to give voice to Arab political and religious parties that had been muzzled for decades. The U.S. views this role as an opportunity to recognize and identify the structures, goals, and activities of these groups. ${ }^{106}$

Regional influence was not the only gain from Doha's good ties with Islamist parties. The Gulf monarchy also benefited from the popularity of these groups in the Arab and Muslim Street, thus bolstering its soft power. Doha managed 
to garner considerable popular support from across the Arab region as a result of its support for the Arab Spring and its close ties with popular Islamist groups. This could be observed in the aftermath of the Gulf crises and following Qatar's winning of the Asia Cup on February 1, 2019. Spontaneous demonstrations to celebrate Qatar's victory erupted in Yemen, Oman, Kuwait, Palestine, Jordan, Morocco, Mauritania, Tunisia, Somalia, and Algeria. ${ }^{107}$

\section{Cultural, Ethical Dynamics: A 'Haven for the Oppressed'}

Cultural and ethical dynamics also serve to explain Doha's policies regarding the Arab Spring. The Qatari leadership justified its supportive positions by noting that they were in line with the principles embodied in the Qatari Constitution, which cites 'ethics' as being among the main foundations for the country's foreign policy. This was drawn from the writings and sayings of the founder of the Emirate, Jassim bin Mohammed al-Thani (1825-1913), who called for helping and sheltering oppressed peoples. Since its founding, the Qatari emirate has been known for harboring opposition figures, including Abdul-Rahman al-Faisal and his son, King Abdul-Aziz, following the demise of the second Saudi State. ${ }^{108}$ Qatar's culture of harboring oppressed peoples and opposition figures was embraced by Emir Hamad bin Khalifa on different occasions in line with Qatar's pro-Arab Spring policies. ${ }^{109}$

Despite not being the main driving force behind Qatar's supportive stance toward revolutionary change in the region since $2011,{ }^{110}$ cultural and ethical dynamics do matter and should be highlighted with a view to understanding Qatari interests and policies, as culture and ethics both constitute key principles in the country's domestic politics. ${ }^{111}$ While public opinion is rarely considered among the Arab Gulf monarchies, it clearly matters in Qatar, where there is a degree of consistency between the regime and society in terms of foreign policy positions. This harmony between the people and the royal family is termed by Kamrava 'popular legitimacy.'112

Qatar's popular legitimacy was confirmed by the Annual Arab Youth Survey for 2012-2013 conducted by the Burson-Marsteller Association, in which Qatar ranked first among 15 Arab countries (Algeria, Bahrain, Egypt, Iraq, Jordan, Kuwait, Lebanon, Libya, Morocco, Oman, Qatar, Saudi Arabia, Tunisia, the UAE, and Yemen) in terms of local youth support for the Arab Spring and a sense of 'Arab Pride' amid the wave of change. Some 66 percent of Qatari youth agreed 'a lot' with this view. ${ }^{113}$ Kamrava asserts:

The Qatari system remains remarkably stable, not so much because of its inherent authoritarianism, but because of its popular legitimacy among an overwhelming majority of Qatari nationals. The regime enjoys considerable legitimacy rooted in a deep nexus between society and the state or, more accurately, between society and the ruling family. ${ }^{114}$ 
With a view to showing how the country's foreign policy is crafted, Qatari leaders stress that the hosting of opposition figures comes in line with principles embraced by state founder Sheikh Jassim bin Mohammed al-Thani. Sheikh Jassim bin Mohammed asserted in one of his poems that he wanted the new state to be a 'Kaabat al-Madiyoum, meaning a 'haven for the dispossessed.' He hoped that the emirate would become a destination for oppressed and exiled peoples, just as Mecca is a haven for Muslims worldwide. Therefore, for decades, Qatar has hosted a variety of exiled leaders and prominent figures from the Muslim Brotherhood, along with advocates of pan-Arabism and senior figures of the Palestinian Liberation Organization (PLO). ${ }^{115}$ Former Hamas Chief Khaled Mishaal lived between Damascus and Doha since 1999, before permanently residing in Qatar following the outbreak of the Syrian Revolution. ${ }^{116}$ Doha has also hosted Yusuf al-Qaradawi, a leading Muslim Brotherhood preacher, since the 1960s, along with controversial Indian artist M.F. Husain and former Iraqi Foreign Minister Naji Sabri al-Hadithi, who was appointed before the U.S. invasion of Iraq in 2003. ${ }^{117}$

The Gulf monarchy also harbored former Chechen President Zalimkhan Yandarbiyev from 1999 to 2004 before he was assassinated by Russian agents in the Qatari capital. Other figures include "Omar bin Laden, a son of Osama bin Laden; much of Saddam Hussain's family (his wife, daughters, and grandsons); ${ }^{118}$ prominent Islamic preachers including the Canadian Bilal Philips and Wagdy Ghoneim; Maaouya Ould Sid Ahmed Taya, former Mauritanian president, and his family; Abbas Madani, former FIS leader in Algeria; prominent Libyan cleric Ali al-Sallabi; and former Knesset member and avowed pan-Arabist Azmi Bishara."119

This diverse collection of exiles represents a range of principles, ideas, and backgrounds. However, most of them were high-profile opposition figures in their home countries, where they struggled against the status quo for decades, subjecting themselves to a considerable danger. Qatar provided a safe haven for them with a view to achieving what its leaders see as their country's longterm political and economic interests. All these exiled individuals enjoyed popular support in their respective countries. ${ }^{120}$

\section{Intervening Factors}

What we mean by 'intervening factors' are the dynamics that helped Qatar take extraordinary measures during the Arab Spring. These policies were not only designed to serve the country's interests in times of revolution, but also during 


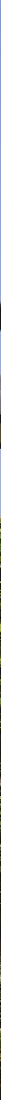

Qatar's Al Jazeera

media network played a major role in mobilizing the Arab masses

that took to

the streets to

demand change.

KARIM JAAFAR /

AFP via Getty

Images previous periods. The explanatory factors included here serve to clarify Qatari exceptionalism in regard to the other Gulf monarchies, with the international system in recent decades allowing small states to assume outsized roles. The absence of domestic threats has also been a contributing factor in this regard. As mentioned above, Doha was among the few Arab monarchies -if not the only one- to see no political unrest upon the outbreak of the Arab Spring. The political unrest that affected Saudi Arabia, Bahrain, Oman, Kuwait, Jordan, and Morocco at the time serves to illustrate the 'exceptional' nature of al-Thani's monarchy.

\section{End of the Cold War and Rise of Small States}

The discipline of International Relations' (IR) realist approach interprets the behavior of small states (small powers) as always being dependent and subordinate to regional hegemons and international powers. However, a new trend has emerged in IR theorization ${ }^{121}$ that gives major significance to the influence of these states, suggesting that small states can exert influence on larger powers if they utilize the potentials at their disposal, such as their strategic locations and resources for which international powers are in dire need. On this basis, many models of relationships between two states (a small one and a large one) have been applied to explain and interpret the dynamics of mutual influence and the impact that small states can have on regional powers and international hegemons. ${ }^{122}$

Major changes in the international system have facilitated Qatar's emergence as an influential player in the regional political arena. In particular, globalization 


\section{Qatar was also among the few countries worldwide that did not feel the shock of the 2008 economic crisis}

has made it easier for small states to punch above their weight, and to exhibit and exert new forms of soft power. Thus, shifting concepts of power in an interdependent world have enabled small states like Qatar to exert much greater influence overseas. During the first decade of this century, the Gulf in general and Qatar, in particular, were seen as effective actors in the global political system. During the oil boom from 2002 to 2008, GCC countries used their energy resources and capital to exert influence vis-à-vis international issues. ${ }^{123}$

The 2008 global economic crisis accelerated the shift toward interdependence in the international political economy. It also provided an opportunity for Qatar to increase its influence on multinational institutions and NGOs. Qatar, for example, joined the World Economic Forum's Global Redesign Initiative, along with Switzerland and Singapore -an initiative that brought 28 small and medium-sized countries together into the G20 orbit. After 2008, as western countries implemented austerity measures, Qatari LNG expansion peaked, with the gross domestic product (GDP) rising by as much as 17 percent annually. ${ }^{124}$

This remarkable growth has provided Qatari policymakers with ample scope to reshape the structure of the international system in an ever-changing world. In May 2009, Prime Minister Hamad bin Jassim addressed these issues directly, calling for a major reshaping of the "regulatory frameworks of the prevailing international political system" following the emergence of a multipolar system in which "the West was no longer the only player in the world." In this context, the Qatari Emir said in March 2009: "China is coming, India is coming, Russia is on its way too... I don't know if the U.S. and Europe will remain in the world command." 125

Qatar, as mentioned above, has taken full advantage of its potential to become a significant player on the regional level, thanks to its policymaking approach and the near-total autonomy enjoyed by its small ruling circle of decision-makers. This autonomy has been largely unaffected by domestic political constraints. $^{126}$

The dynamism of Qatari foreign policy during the post-1995 period constituted a challenge to the existing theoretical approach, according to which only large countries can launch initiatives (such as mediation efforts) on the regional and international levels, while small countries are confined to roles of attendance and enrollment. This dynamism has also challenged the view, formulated by Handel ${ }^{127}$ and other theorists, that small states cannot develop in- 


\section{It is worth noting that the role Qatar played during the Arab Spring was also affected by intervening factors, mainly its secure domestic conditions}

dependent policies vis-à-vis international issues. ${ }^{128}$ However, the Qatari case reveals a small state's willingness to offset -and even compete withlarger political players on substantial issues, regardless of its smaller size and capabilities. ${ }^{129}$

The clearest example of this was Al Jazeera's coverage of the U.S. invasion and occupation of Iraq. Qatar angered its U.S. ally due to its influential Al Jazeera news outlet, which aired anti-invasion coverage that exposed abuses and human rights violations by U.S. forces during the eight-year occupation. ${ }^{130}$ In 2008, Saudi Arabia was outraged when Qatar hosted various Lebanese opposition factions, including Iran-backed Hezbollah, which is hostile to the West, at a peace conference in Doha. The following year, the U.S., Saudi Arabia, and Egypt were similarly enraged when Qatar hosted mediation efforts between Palestinian groups Fatah and Hamas. In response to the move, Riyadh, and Cairo boycotted meetings on the Gaza crisis held in Doha in 2009. The boycott came as Doha 'tried to maneuver' for more influence on the Palestinian file, which for decades had been the exclusive preserve of Riyadh and Cairo. ${ }^{131}$

To sum up, the mediation role that Qatar has played over the past two decades has given Doha enormous influence in both regional and international arenas. This coincided, as mentioned previously, with the rise of an ambitious political elite that governed the country and took advantage of various dynamics to help Qatar's leadership raise its regional status, despite the country's relatively small size and population. This also coincided with the retreat of classical interpretations of the role of small states in international politics.

\section{The Absence of Domestic Threats}

Recent years have seen Qatar become a successful model for other Gulf countries in terms of economy, education, health, and sports, not to mention the fact that per capita GDP for Qataris was the world's highest in 2011 and has remained within the top three over the last decade. ${ }^{132}$

The level of individual income for Qatari citizens was very high in 2011, which constituted a unique situation in the MENA region, prompting Doha to rule out any possibility of economic turmoil or local political dissatisfaction, with per capita GDP hitting $\$ 147,000$ in the year that the Arab Spring erupted. ${ }^{133}$ Doha's vast wealth, and the general satisfaction of its citizens, contributed to protecting the country from the unrest that engulfed other states of the region. Qatar's level of wealth, along with its small population, led to political apathy among the Qatari people and tempered their democratic aspirations, with few Qataris, if any, inclined to challenge the status quo. ${ }^{134}$ 
A handful of opinion surveys carried out by Qatar University's Social and Economic Survey Research Institute (SESRI) showed that citizens' confidence in government institutions had increased considerably in the wake of the Arab Spring, while interest in politics and democracy had moved in the opposite direction. ${ }^{135}$ According to the results of an Arab Youth Survey carried out in 2010, the number of citizens who viewed democracy as 'significant' fell by more than half -from 68 percent in 2008 to 33 percent in 2010. These results illustrate the difference between Qatar and its Gulf counterparts. In the UAE, for example, the number rose from 58 percent in 2008 to 75 percent in $2011 .{ }^{136}$

When protests broke out in Tunisia in late 2010, then, the Qatari leadership was in a very favorable position, as the protests came in the midst of Doha's winning its bid to host the 2022 World Cup, which was seen as a recognition of the emirate's influence in the Gulf and the wider Middle East. ${ }^{137}$ With this development, the Qatari leadership seized the opportunity to classify its country as 'totally safe' from the unrest then plaguing the region. Confident that their country would remain immune from the protests, Qatari policymakers adopted a clear stance against authoritarian regimes in North Africa and Syria. They were also confident that their financial, media, and material support for opposition movements in these countries would have no domestic consequences, believing that this generous support would make Qatar a major player in regional and international arenas. ${ }^{138}$ However, some Qatari opposition figures became active -mainly on social media- following the 2017 Gulf crisis, with Saudi-backed activists like Mona al-Sulaiti and Khaled al-Hail openly criticizing the Qatari authorities. ${ }^{139}$ The latter, however, downplayed this criticism, calling it 'fake and intentionally invented by Riyadh and Abu Dhabi.' ${ }^{140}$

Qatar was also among the few countries worldwide that did not feel the shock of the 2008 economic crisis. ${ }^{141}$ Doha hosts Arab advisors from all over the region who typically tell the Qatari government to expect low oil prices when devising their annual budget. This solid advice has helped Doha avoid many financial crises, including those of 1997 and 2008, ${ }^{142}$ and it goes hand in hand with prudent management and good governance. Having a large number of advisors from across the Arab world, and depending on their advice for critical issues, can be termed 'Practicing Consultation in a Royal Court's Context.' This means that no one, regardless of rank or position, makes critical economic, political, or strategic decisions alone. ${ }^{143}$

\section{Conclusion}

Unlike its neighboring monarchies, Qatar was supportive of almost all the uprisings that took place within its geopolitical reach. Qatari backing varied from 
media support through Al Jazeera to financial, military, and diplomatic forms of support.

There are many driving and intervening factors that help us understand the motives behind Qatar's pro-revolution policies. A strive for more influence is the main dynamic behind Doha's pro-change positions. This coincided with the rise of an ambitious political elite represented by the 'Two Hamads.' Doha's bid to counter Saudi hegemony in the region also matters and is one of the main reasons for Doha's behavior. Qatar has refused to act as a passive or dependent entity in the Gulf (as others do). Qatar also challenged Saudi influence in Egypt by allying itself with pro-change movements there, achieving substantial influence in the year and a half following Mubarak's ouster.

Competition with the UAE should also be underlined as one of the main geopolitical motives behind Qatari policies. This competition is to a large extent over Egypt, reflecting longstanding tribal jealousies. Following Egypt's Revolution, Qatar allied itself with revolutionary figures, while the UAE backed anti-revolution personalities and groups.

Furthermore, Qatar benefitted from its close ties with the U.S. and various Islamist groups to accrue more power and influence. Doha has been one of the few Arab countries, and the only Arab monarchy, to emphasize on different occasions that Islamist groups represent wide swathes of the Arab public and should therefore be included in political processes.

It is worth noting that the role Qatar played during the Arab Spring was also affected by intervening factors, mainly its secure domestic conditions. The cultural dynamic should be highlighted with a view to understanding Qatar's interests, as the Qatari people largely backed the country's pro-Arab Spring policies, reflecting Doha's 'popular legitimacy'.

\section{Endnotes}

1. Fred Halliday, Revolution and World Politics: The Rise and Fall of the Sixth Great Power, (Durham: Duke University Press, 1999), pp. 208-2011.

2. Interview, Khalil al-Anani, John Hopkins University, June 24, 2019, via Zoom.

3. Interview, Saif Abdel-Fattah, Egyptian thinker, and advisor, May 17, 2019, via Zoom.

4. Interview, Majed al-Ansari, Doha University, June 8, 2019, via Zoom.

5. By this term, we refer to the former Emir Hamad bin Khalifa and his Prime Minister, and Foreign Minister Hamad bin Jassem.

6. Babak Mohammadzadeh, "Status and Foreign Policy Change in Small States: Qatar's Emergence in Perspective," The International Spectator, Vol. 52, No. 2 (2017), pp. 19-36.

7. Jamal Abdullah, "Analysis: Qatar's Foreign Policy, the Old and the New," Al Jazeera, (November 21, 2014), retrieved July 17, 2020, from https://www.aljazeera.com/opinions/2014/11/21/analysis-qatarsforeign-policy-the-old-and-the-new. 
8. Christopher Phillips, The Battle for Syria: International Rivalry in the New Middle East, (Connecticut: Yale University Press, 2016) p. 37.

9. Lori Plotkin Boghardt, "The Doha Conference: A Post-Mortem," The Washington Institute, retrieved September 20, 2020, from https://www.washingtoninstitute.org/policy-analysis/view/the-doha-conference-a-post-mortem.

10. Boghardt, "The Doha Conference."

11. "Emir Hamad bin Khalifa Speech at the UN's General Assembly Meetings in 2011," Amiri Court, retrieved on July 20, 2020 from https://www.youtube.com/watch?v=TxeHMQ58fwQ\&ab_channel= AmiriDiwan; "Emir Hamad bin Khalifa Speech at the UN's General Assembly Meetings in 2012," Amiri Court and Russia Today, retrieved on July 20, 2020, from https://www.youtube.com/watch?v=99DGtRxENZc\&ab_channel=RTArabic.

12. "Will Qatar's New Emir Change Doha's Foreign Policy," France24, retrieved December 15, 2019 from https://www.france24.com/ar/20130726; "Engineer of Qatar's Foreign Policy Comes Back," Sasapost, retrieved June 17, 2020, from https://web.archive.org/web/20190401021811/https://www.sasapost. com/sheikh-hamad-bin-jassem-the-architect-of-qatars-regional-policy-is-back/.

13. "Engineer of Qatar's Foreign Policy Comes Back."

14. Boghardt, "The Doha Conference."

15. "In 23 Years, Al-Jazeera as Qatari-Platform Trusted by Peoples," al-Khaleej, retrieved June 17, 2020 from https://alkhaleejonline.net/\%D8\%AB\%D9\%82\%D8\%A7\%D9\%81\%D8\%A9.

16. Interview, Saif Abdel-Fattah.

17. Boghardt, "Engineer of Qatar's Foreign Policy Comes Back."

18. Boghardt, "Engineer of Qatar's Foreign Policy Comes Back."

19. "Hamad bin Jassem Speaking to al-Jazeera," Al Jazeera, retrieved July 17, 2020, from https://www. youtube.com/watch?v=seiABoeLxDo\&ab_channel=AlJazeeraChannel\%D9\%82\%.

20. "Hamad bin Jassem Speaking to al-Jazeera."

21. "Former Qatari PM Has Eyes on Top UN Job," The Telegraph, retrieved December 15, 2019, from https://www.telegraph.co.uk/news/uknews/11172018/Former-Qatari-PM-has-eyes-on-top-UN-job. html.

22. Interview, Abdel-Fattah.

23. Interview, Abdel-Fattah.

24. Interview, Abdel-Fattah .

25. Interview, Majed al-Ansari.

26. David B. Roberts, "The Four Eras of Qatar's Foreign Policy," Comillas Journal of International Relations Vol. 5 (2016), pp. 7-9.

27. Roberts, "The Four Eras of Qatar's Foreign Policy," p. 9.

28. "Qatari-Saudi Relations: A History of Conflicts and Tensions," BBC, retrieved October 15, 2019, from https://www.bbc.com/arabic/middleeast-40172427.

29. "Qatari-Saudi Relations."

30. Ali Fawwaz, "Origin of the Saudi-Qatari Story," al-Mayadeen News, (June 19, 2017).

31. Bani Murra is a well-known Arab tribe descended from the Banu Yam tribe and scattered in the Gulf countries of Qatar, Kuwait, Yemen, Saudi Arabia, Bahrain, and the UAE. Robert L. Headley, "People of the Camel," Aramco World, Vol. 15, No. 5 (September/October 1964), retrieved April 19, 2020, from https:// archive.aramcoworld.com/issue/196405/people.of.the.camel.htm.

32. Qatar-Israel relations dates back to 1996, when Doha established trade relations with Israel before severing them following Israel's offensive against Gaza in 2009.

33. Headley, "People of the Camel." 
34. Headley, "People of the Camel."

35. "Doha Summit: A Controversial Iranian Day," al-Sharq al-Awsat, retrieved September 18, 2020, from https://archive.aawsat.com/details.asp?article=448341\&issueno=10598\#.X3NP8pMzZQI.

36. Mohammed al-Misfir, Gulf Conflicts and the Strategic Gap Challenge, (Doha: Al Jazeera Center for Researches and Studies, 2018).

37. Interview, Professor Khalil al-Anani, John Hopkins University, June 24, 2020, via Zoom.

38. "Qatar and Saudi Arabia... Disputes Sparked by Storms of the Arab Spring," Masr al-Arabiyya, retrieved October 15, 2019, from http://www.masralarabia.com/1440975.

39. Bayram Sinkaya, "Implications of the Arab Spring for Iran's Policy towards the Middle East," Middle Eastern Studies, Vol. 6, No. 2 (2015), p. 57.

40. Rawan Kanaan, "Saudi-Qatari Relations: From Cooperation to Clash," Master's thesis, Lebanese University, 2017, p. 44.

41. Interview, al-Anani.

42. Vijad Parshay, "Saudi Arabia Wants Qatar to Come Under Its Heel: Even Old Saudi Allies Aren't Exactly Going Along with That," Salon, (June 18, 2017), retrieved from https://www.salon.com/2017/06/18/ saudi-arabia-wants-qatar-to-come-under-its-heel-even-old-saudi-allies-arent-exactly-going-alongwith-that_partner/.

43. Kareem Asaad, "Bahrain Is a Saudi Province: Why Does a State Accept Dependency?" Idaat, July 4, 2018.

44. Interview, al-Anani.

45. Parshay, "Saudi Arabia Wants Qatar to Come Under Its Heel"; See, Asaad, "Bahrain Is a Saudi Province: Why Does a State Accept Dependency?"

46. These conditions were seen by many experts and academics as a blatant violation of the Qatari sovereignty, foremost the condition to shut Al Jazeera down and the one asking Doha to abandon its military cooperation with Turkey.

47. "Arab States Issue 13 Demands to End Qatar-Gulf Crisis," Al Jazeera, (July 12, 2017) retrieved December 17, 2019, from https://www.aljazeera.com/news/2017/06/arab-states-issue-list-demands-qatar-crisis-170623022133024.html.

48. Liz Sly, "Princely Feuds in the Persian Gulf Thwart Trump's Efforts to Resolve the Qatar Dispute," The Washington Post, (May 13, 2018), retrieved May 12, 2020 from https://www.washingtonpost. com/world/princely-feuds-in-the-persian-gulf-thwart-trumps-efforts-to-resolve-the-qatar-dispute/2018/05/13/7853cc88-39cf-11e8-af3c-2123715f78df_story.html.

49. Liz Sly, "Princely Feuds in the Persian Gulf Thwart Trump's Efforts to Resolve the Qatar Dispute."

50. Interview, Egyptian former Investment Minister Yahya Hamed, (June 1, 2020), via Zoom.

51. Interview, Hamed.

52. Interview, Hamed.

53. Interview, al-Anani.

54. Interview, Hamed.

55. Ali Aslan, "Why Qatar and Saudi Arabia Are Clashing," Rouya Turkiyyah, Vol. 6, No. 4 (2017), pp. 2-3.

56. Aslan, "Why Qatar and Saudi Arabia Are Clashing," p. 3.

57. Aslan, "Why Qatar and Saudi Arabia Are Clashing," p. 3.

58. "Qatar Pardons Prisoners of Failed Coup Attempt," CNN, retrieved May 5, 2020, from http://archive. arabic.cnn.com/2010/middle_east/5/25/qatar.saudi/.

59. "Emir of Qatar Deposed by His Son," The Independent, retrieved September 17, 2020, from https:// www.independent.co.uk/news/world/emir-of-qatar-deposed-by-his-son-1588698.html. 
60. "Poems Traded Between Emir Zayed and Emir Khalifa bin Hamad," al-Bayan Daily, retrieved September 17, 2020, from https://www.albayan.ae/one-world/arabs/2018-04-02-1.3226895.

61. Interview, Palestinian researcher, and writer Sary Sammour, September 27, 2020, via Zoom.

62. "One of 1996's Coup Leaders Reveal New Details," al-Sharq Daily, retrieved May 5, 2020, https://alsharq.com/article/24/12/2018/.

63. "UAE Officially Responds to Qatari Accusations Regarding 1996's Coup," Sputnik, retrieved May 12, 2020, from https://arabic.sputniknews.com/arab_world/201812171037552899.

64. "What Was Hidden Is Greater: 1996 Coup," Al Jazeera, retrieved May 12, 2020, from https://www. youtube.com/watch?v=rcyP_b435TQ.

65. Mohammed al-Baz, The Fall of the Gods: How Mubarak and His Men Collapse, (Cairo: al-Ward Island Publishing House, 2011), pp. 115-116.

66. Interview, Abdel-Fattah.

67. Interview, Abdel-Fattah.

68. "Leaked Documents Expose Stunning Plan to Wage Financial War on Qatar-and Steal the World Cup," The Intercept, November 8, 2017, retrieved September 19, 2020, from https://medium.com/ theintercept/leaked-documents-expose-stunning-plan-to-wage-financial-war-on-qatar-and-steal-theworld-cup-a2ccf802fa0c.

69. "UAE Planned to Thwart Qatar's Hosting for the 2022 World Cup."

70. Dandarawi al-Hawwari, "Will FIFA Drop Qatari Right to Host 2022 World Cup?" Youm-7 Daily, (March 7, 2015).

71. "UAE Planned to Thwart Qatar's Hosting for the 2022 World Cup."

72. "Mubarak Receives UAE's Foreign Minister," Elaph News, retrieved July 17, 2020 from https://elaph. com/Web/news/2011/2/630430.html.

73. Liz Sly, "Princely Feuds in the Persian Gulf Thwart Trump's Efforts to Resolve the Qatar Dispute," The Washington Post, (May 13, 2018), retrieved from https://www.washingtonpost.com/world/princelyfeuds-in-the-persian-gulf-thwart-trumps-efforts-to-resolve-the-qatar-dispute/2018/05/13/7853cc8839cf-11e8-af3c-2123715f78df_story.html.

74. "Qatar's $\$ 129,000$ Average Income Is Double Saudi Arabia's: Chart," Bloomberg, (June 8, 2017), retrieved September 25, 2020, from https://www.bloomberg.com/news/articles/2017-06-08/qatar-s-129000-average-income-is-double-saudi-arabia-s-chart.

75. Interview, al-Anani.

76. Antonino Occhiuto, "Balance of Interests: The UAE-Qatar Competition," Euro-Gulf Information Center, (May/June 2018) p. 2.

77. Interview, al-Anani.

78. Interview, al-Anani.

79. Interview, al-Anani.

80. "Morsi's Speech on June 27, 2013," MBC Egypt, retrieved on June 19, 2020, from https://www.youtube.com/watch?v=TPwBswZ7cng.

81. "How the UAE Undermined the Arab Spring," Sasapost, retrieved December 17, 2018 from https:// www.sasapost.com/why-emirates-against-the-arabic-spring/.

82. Al-Arabi, "How the UAE Undermined the Arab Spring."

83. Saudi Arabia, United Arab Emirates, Bahrain, and Egypt.

84. David B. Roberts, "Reflecting on Qatar's 'Islamist'Soft Power," Brookings Institution, (2019), p. 6.

85. Roberts, "Reflecting on Qatar's 'Islamist' Soft Power," p. 6.

86. "Interview with Hamad bin Jassim," Charlie Rose, retrieved August 27, 2020, from https://charlierose. com/videos/17340. 
87. However, Qatar waived good ties Islamic groups who don't believe in democracy as a way to reach power, ex. al-Nusra and the Taliban.

88. Interview, Abdel-Fattah, al-Anani.

89. Interview, Abdel-Fattah, al-Anani.

90. Interview, Abdel-Fattah, al-Anani.

91. Interview, Abdel-Fattah, al-Anani.

92. Roberts, "Reflecting on Qatar's 'Islamist' Soft Power," p. 7.

93. "His Highness' Interview on CNN."

94. "His Highness' Interview on CNN."

95. "His Highness' Interview on CNN."

96. Anne R. Pierce, "US 'Partnership' with the Egyptian Muslim Brotherhood and Its Effect on Civil Society and Human Rights," Society, Vol. 51, No. 1 (2014), pp. 68-69.

97. Interview, al-Anani, al-Ansari.

98. "Qatar and the MB, New-Old Ties," Hafryat, retrieved July 19, 2020, from https://hafryat.com/ar/ blog/\%D9\%82\%D8\%B7\%D8\%B1.

99. Interview, Abdel-Fattah.

100. U.S.-Taliban talks were held in December 2018 in the UAE to reach a political exit for the Afghani crisis but ended with no breakthrough.

101. "Taliban Leaders Meet U.S. Officials in UAE over Afghan Peace Effort," The National, (December 17, 2018), retrieved June 17, 2020, from https://www.thenational.ae/world/gcc/taliban-meet-us-officialsin-uae-over-afghan-peace-effort-1.803645.

102. Trump's team was enthusiastic either for the UAE's plea before the whole bid utterly failed.

103. Interview, Abdel-Fattah, al-Anani.

104. Interview, Abdel-Fattah, al-Anani.

105. Interview, Abdel-Fattah, al-Anani.

106. Interview, Abdel-Fattah, al-Anani.

107. "Why Arabs Are Happy for Qatar Defeating UAE," Gulf Online, retrieved June 17, 2020, from https:// alkhaleejonline.net/9F.

108. Abdul-Aziz al-Owayyid, "Kaabat al-Madyoum and the Founder of the Qatari State," retrieved on April 17, 2020, from https://www.youtube.com/watch?v=dmiiaDQyTyk.

109. Abdullah al-Athba, "Qatar: Kabbat al-Madyoum," al-Arab Daily, (November 6, 2012).

110. Interview, al-Ansari.

111. Interview, Abdel-Fattah.

112. Mehran Kamrava, Qatar: Small State, Big Politics, (New York: Cornell University Press, 2013), p. 14.

113. "Bursun-Marsteller Arab Youth Survey," Asdaabm.com, retrieved July 27, 2020, from http://www. arabyouthsurvey.com/pdf/whitepaper/en/2013-AYS-White-Paper.pdf.

114. Kamrava, Qatar, p. 14.

115. Ex. Palestinian President Mahmoud Abbas and his family hold Qatari citizenship.

116. David Roberts, "Qatar and the Muslim Brotherhood: Pragmatism or Preference?" Middle East Policy, Vol. 21, No. 3 (2014), pp. 84-86.

117. Al-Qaradawi, retrieved November 12, 2019, from https://www.al-qaradawi.net/.

118. "Interview Given by Harir Saddam Hussein to al-Khaleej Online," al-Khaleej, retrieved November 12, 2019, from https://alkhaleejonline.net. 
119. Roberts, "Qatar and the Muslim Brotherhood," p. 85.

120. Andrew Lipp, The Muslim Brotherhood: Exploring Divergent Views in Saudi Arabia and Qatar, (lowa ProQuest Dissertations Publishing, 2019) p. 11; see, "Interview with the Qatari Former PM Hamad bin Jassim," BBC, retrieved June 17, 2020, from https://www.youtube.com/watch?v=w8QMRb4mM0c.

121. Realism and its branch schools (classical realism and structural realism - neo-realism) have remained as the dominant school of thought in the International Relations studies since the establishment of the IR discipline in the early 1900 s.

122. Robert O. Keohane, "The Big Influence of Small Allies," Foreign Policy, No. 2 (1971), pp. 161-182, quoted by Kanaan, Saudi-Qatari Relations: From Cooperation to Clash, p. 9.

123. Ulrichsen, "Qatar and the Arab Spring," pp. 6-7.

124. Ulrichsen, "Qatar and the Arab Spring," p. 7.

125. Ulrichsen, "Qatar and the Arab Spring," p. 8.

126. Ulrichsen, "Qatar and the Arab Spring," p. 8.

127. Michael Handel, Weak States in the International System, (London: Frank Cass, 1990); Maurice A. East, "Size and Foreign Policy Behavior: A Test of Two Models," World Politics, Vol. 25, (1973), pp. 556-576.

128. Rory Miler, "Qatar's Resilience: A Model of Resisting Blockade and the Power of Small States," Al Jazeera Center for Studies, (April 1, 2018).

129. Miler, "Qatar's Resilience."

130. Miler, "Qatar's Resilience."

131. Miler, "Qatar's Resilience."

132. "Qatar's $\$ 129,000$ Average Income Is Double Saudi Arabia's."

133. "GDP Per Capita: Qatar," World Bank, retrieved December 17, 2019, from https://data.worldbank. org/indicator/NY.GDP.PCAP.CD?locations=QA\&view=chart.

134. Ulrichsen, "Qatar and the Arab Spring," p. 9.

135. Justin Gengler, "The Political Costs of Qatar's Western Orientation," Middle East Policy, Vol. 19, No. 4 (Winter 2012) pp. 68-76.

136. Here we should note that Qataris in general do not feel deprived. Unlike in Qatar, protests were seen in other Gulf monarchies, including Bahrain, Kuwait, and Saudi Arabia. In Bahrain, Shias protested their bad conditions, while Kuwait and Saudi Arabia's 'Bidoun' population took to the streets to demand greater rights. See, Ulrichsen, “Qatar and the Arab Spring," pp. 9-10.

137. Ulrichsen, "Qatar and the Arab Spring," pp. 9-10.

138. Ulrichsen, "Qatar and the Arab Spring," pp. 9-10.

139. "Head of Qatari Opposition to Launch Community Debate Center in London," Arab News, (May 21, 2019), retrieved December 25, 2019, from https://www.arabnews.com/node/1499291/world.

140. "Questions Raised Over Paid Protest Timed for Qatari Leader's No. 10 Visit," The Guardian, (July 23, 2018), retrieved December 12, 2019, from https://www.theguardian.com/world/2018/jul/23/qataraccuses-gulf-rivals-of-paying-for-political-protest-in-london.

141. Interview, Abdel-Fattah.

142. Interview, Abdel-Fattah.

143. Interview, Abdel-Fattah. 


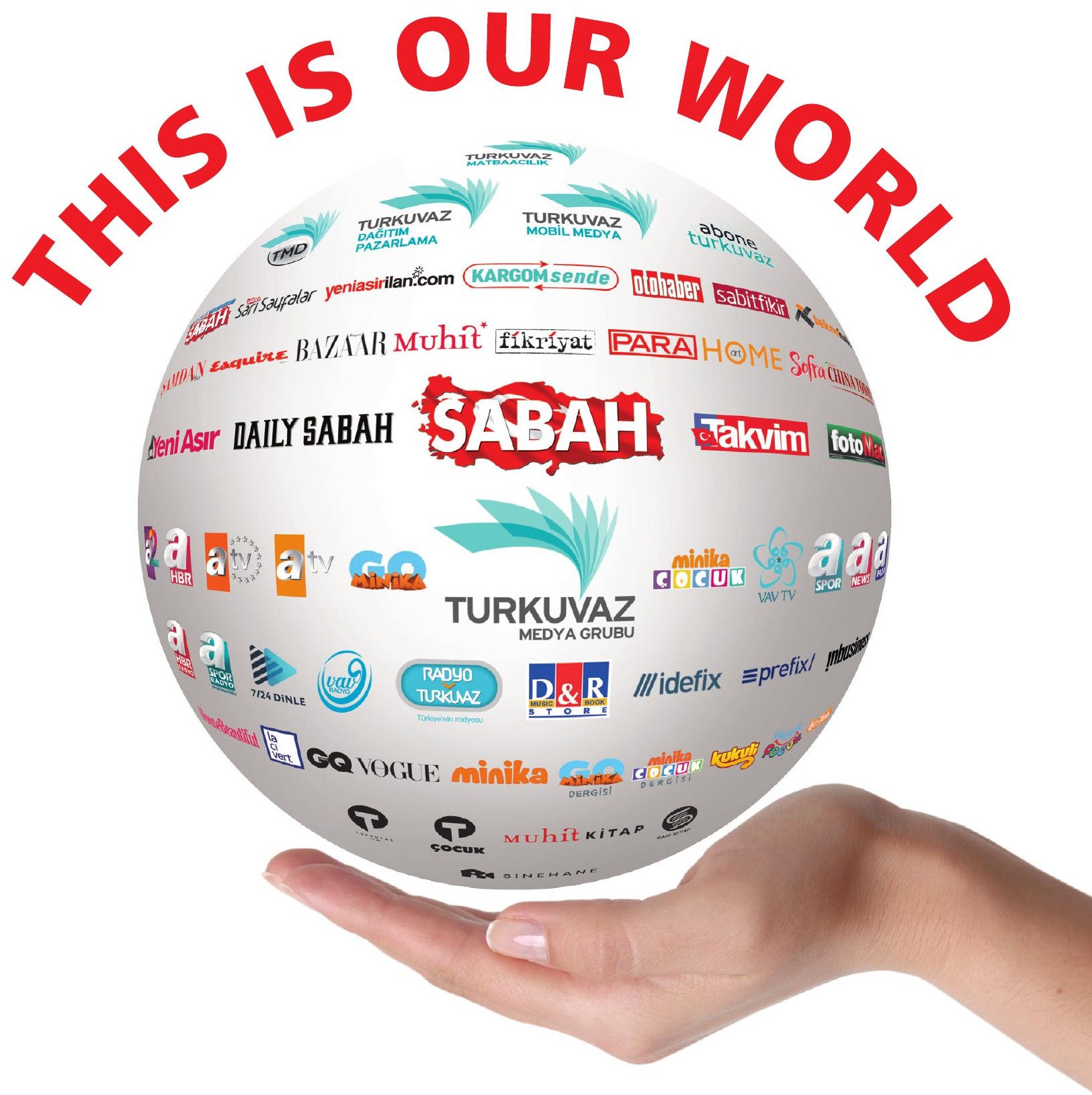

Turkuvaz Media Group is the leading group of companies which deals with broadcasting, publishing and distribution activities in Turkey. Most reputable national and international magazines, best selling local and national newspapers and prestigious tv channels create the most powerful synergy in Turkish media.

The opportunity to utilize this power for your advertisements is in your hands. Why not use it? 